\title{
EFFECTS OF ROOT PLANT AND LITTER ON SOIL MACROPOROSITY, INFILTATION RATE AND EROSION
}

\section{EFEK PERAKARAN TANAMAN DAN SERASAH TERHADAP MAKROPOROSITAS TANAH, LAJU INFILTRASI DAN EROSI}

\author{
E. Hanggari Sittadewi ${ }^{1}$ \\ 1 Pusat Teknologi Reduksi Risiko Bencana - TPSA - BPPT \\ Gedung BPPT Lantai 12, JI. M. H. Thamrin No. 8, Jakarta Pusat 10340 \\ e-mail: sittadewi57@gmail.com
}

\begin{abstract}
Plant roots and litter produced by trees have an important role in the entry of rainwater into the soil (infiltration) which then becomes water storage in the soil. The effects of plant roots and litter on increasing infiltration rate is due to increased soil macroporosity. The presence of roots that spread in various layers in the soil profile will further increase the organic matter content of the soil and loosen the soil, thereby increasing soil macroporosity. In addition, dead roots will form empty spaces that can be filled by infiltration water, as well as active roots that have gaps between roots and soil that can be filled infiltration water. The higher infiltration rate will reduce the amount of excessive runoff water so as to reduce the occurrence of erosion.
\end{abstract}

Keywords: plant roots and litter, infiltration rate, soil macroporosity, erosion

\begin{abstract}
Abstrak
Perakaran tanaman dan serasah yang dihasilkan oleh tegakan pohon yang tumbuh di atasnya mempunyai peran yang penting terhadap masuknya air hujan ke dalam tanah (infiltrasi) sebagai simpanan air di masa mendatang. Efek dari perakaran tanaman dan serasah terhadap meningkatnya laju infiltrasi dikarenakan oleh makroporositas tanah yang meningkat. Keberadaan akar yang menyebar di berbagai lapisan dalam profil tanah akan lebih meningkatkan kandungan bahan organik tanah dan menggemburkan tanah sehingga meningkatkan makroporositas tanah. Selain itu akar yang telah mati akan membentuk ruang kosong yang dapat terisi air infiltrasi, demikian juga akar yang masih aktif memiliki celah antara akar dan tanah yang dapat terisi oleh air infiltrasi. Tingginya laju infiltrasi akan mengurangi jumlah air limpasan yang berlebihan sehingga dapat mengurangi terjadinya erosi.
\end{abstract}

Keywords : perakaran tanaman dan serasah, laju infiltrasi, makroporositas tanah, erosi 


\section{PENDAHULUAN}

Porositas tanah akan meningkatkan kadar air pada kondisi kapasitas lapang dimana kandungan air dalam tanah berada dalam kondisi maksimum yang dapat ditahan oleh partikel tanah akibat gaya gravitasi. Dijumpai adanya pori besar dan pori kecil dalam tanah. Faharani et al (2009) mengatakan bahwa makroporositas tanah merupakan salah satu aspek yang mempengaruhi infiltrasi air ke dalam tanah dan menjadi indikator kualitas fisik tanah secara umum. Perakaran tanaman dan serasah mempunyai peran terhadap perbaikan kualitas fisik tanah karena adanya peningkatan makroporositas. Menyebarnya akar di lapisan tanah meningkatkan kandungan bahan organik tanah dan melonggarkan pori - pori tanah, kemudian meningkatkan volume air yang meresap ke dalam tanah (Asdak, 1995). Selain karena perakaran tanaman dan serasah, makroporositas dapat dipengaruhi oleh beberapa faktor lain yaitu celah yang terbentuk dari pemadatan matriks tanah, aktifitas hewan tanah serta pembengkakan, perekahan, dan pengkerutan tanah (Rivenshield \& Bassuk, 2007).

Infiltrasi adalah proses aliran air (umumnya berasal dari curah hujan) masuk ke dalam tanah sebagai akibat gaya kapiler (gerakan air ke arah vertikal). Setelah lapisan tanah bagian atas jenuh, kelebihan air tersebut mengalir ke tanah yang lebih dalam sebagai akibat gaya gravitasi bumi dikenal sebagai proses perkolasi (Asdak, 2002). Air infiltrasi merupakan unsur penting dalam daur hidrologi di alam dan merupakan salah satu sumber kesediaan air di masa mendatang. Pada proses alami, jatuhan air hujan akan terdistribusi ke dalam dua bagian, yaitu bagian yang jatuh mengenai dan ditahan tajuk dan batang, sebagian lagi jatuh sampai ke permukaan tanah. Air yang jatuh ke permukaan tanah akan terdistribusi lagi menjadi air infiltrasi dan air limpasan. Air limpasan yang berlebihan akan menyebabkan terjadinya erosi, sebaliknya air infiltrasi yang masuk dan mengisi pori-pori tanah akan menjadi simpanan air di masa mendatang. Menurut Hairiah et al (2006) terdapat hubungan yang positif antara makroporositas dengan infiltrasi konstan. Semakin tinggi makroporositas tanah maka infiltrasi konstan juga semakin meningkat. Tanah dengan jumlah pori makro yang banyak akan mempunyai laju infiltrasi yang lebih tinggi dibandingkan tanah dengan pori makro kecil meskipun jumlah total pori sama.

Dalam studi ini akan dilakukan analisa dan pembahasan baik dari bahan literatur maupun penelitian terdahulu tentang efek dari perakaran tanaman dan serasah terhadap peningkatan makroporositas, laju infiltrasi dan erosi. Diharapkan dari hasil studi ini dapat dijadikan referensi dalam penelitian selanjutnya terutama dalam implikasinya untuk mitigasi erosi.

\section{METODE}

Studi tentang efek perakaran dan serasah terhadap makroporositas tanah, laju infiltrasi dan erosi dilakukan dengan beberapa langkah dan metode sebagai berikut:

- Melakukan studi pustaka dan literatur baik data, informasi, maupun penelitian sebelumnya dari jurnal, buku atau website.

- Mendiskripsikan tentang adanya korelasi positif antara porositas dan infiltrasi tanah.

- Mendeskripsikan tentang adanya pengaruh/efek perakaran dan serasah terhadap makroporositas tanah dan laju infiltrasi.

- Mendeskripsikan tentang peran vegetasi dan perakaran terhadap mitigasi erosi.

- Melakukan pembahasan secara menyeluruh tentang efek perakaran dan serasah terhadap makroporositas tanah dan korelasi positifnya terhadap laju infiltrasi dan mitigasi erosi.

\section{HASIL DAN PEMBAHASAN}

\subsection{Korelasi Positif Antara Porositas Dan Infiltrasi Tanah.}

Porositas adalah proporsi ruang pori total (ruang kosong) yang terdapat dalam satuan volume tanah yang dapat ditempati oleh air tanah dan udara, merupakan indikator kondisi drainase dan aerasi tanah (Hanafiah, 2005). Laju infiltrasi (infiltration rate) adalah banyaknya air per satuan waktu 
yang masuk melalui permukaan tanah (Arsyad, 2006). Vegetasi dan porositas adalah faktor penting yang mempengaruhi laju infiltrasi, selain kondisi tanah yang lain seperti tekstur, stabilitas agregat tanah, kelembaban serta unsur organik dalam tanah. Hal inilah yang menyebabkan laju infiltrasi pada tanah berbeda-beda. Keberadaan dan jumlah pori - pori di dalam tanah sangat bergantung dengan adanya vegetasi dan aktivitas biologi tanah. Jumlah dan ukuran pori yang menentukan infiltrasi adalah jumlah pori - pori yang berukuran besar. Semakin banyak pori-pori besar yang terbentuk, maka kapasitas infiltrasi juga semakin besar. Kapasitas infiltrasi merupakan kemampuan tanah untuk menyerap air infiltrasi masuk ke dalam tanah secara vertikal dalam suatu waktu (Elfiati dan Devian, 2010). Seperti disebutkan di bab pendahuluan, bahwa antara makroporositas dengan infiltrasi konstan mempunyai kecenderungan berkorelasi positif. Beberapa hasil penelitian yang berkaitan dengan hal tersebut antara lain, Hairiah et al (2006) menyimpulkan bahwa makroporositas berkorelasi positif terhadap resapan air, makroporositas yang lebih tinggi akan menyebabkan infiltrasi konstan yang lebih tinggi. Aziz (2011) melaporkan bahwa $79 \%$ peningkatan jumlah pori makro tanah diikuti oleh peningkatan infiltrasi konstan. Selanjutnya dari ketiga model persamaan laju infiltrasi dari penelitian Darmayanti (2012), faktor sifat fisika tanah yang paling berpengaruh terhadap infiltrasi adalah prosentase makroporositas.

\subsection{Efek Perakaran Tanaman Dan Serasah Terhadap Makroporositas Tanah}

Makroporositas banyak dipengaruhi oleh aktifitas perakaran. Aktifitas perakaran yang tinggi di dalam tanah yang ditandai dengan nilai panjang dan berat akar yang besar akan membentuk makroporositas. Keberadaan akar yang menyebar di berbagai lapisan dalam profil tanah akan meningkatkan kandungan bahan organik tanah dan menggemburkan tanah sehingga akan meningkatkan jumlah air yang masuk ke dalam tanah. Namun dikatakan oleh
Sasal et al (2006), bahwa akar-akar yang menyebar ke arah samping kurang efektif dalam pergerakan air dibanding dengan akar yang berorientasi vertikal. Hal tersebut menyebabkan makroporositas vertikal yang terbentuk rendah karena air hujan seperti halnya akan mengalir ke samping (lateral). Perakaran tanaman yang terbentuk yang dapat mempengaruhi makroporositas dapat berupa akar yang masih aktif ataupun akar yang telah mati. Akar yang telah mati akan membentuk ruang kosong yang dapat terisi oleh air infiltrasi, demikian juga akar yang aktif memiliki celah antara akar dan tanah yang dapat terisi oleh air infiltrasi.

Selain keberadaan bahan organik dalam tanah, serasah tanaman juga faktor yang sangat penting untuk meningkatkan laju infiltrasi. Serasah yang dihasilkan oleh vegetasi akan dirombak oleh aktifitas hewan tanah dan mikroba. Peningkatan kandungan bahan organik tanah akan memicu aktifnya organisme dalam tanah, semakin tinggi aktifitas organisme tanah khususnya yang berperan sebagai pengelola ekosistem mampu memperbaiki porositas dan stabilitas agregat tanah (Cardoso et al, 2013). Rivenshield \& Bassuk (2007) mengatakan bahwa sebagai bahan organik di permukaan tanah, serasah merupakan bagian tumbuhan yang juga mempengaruhi infiltrasi air ke dalam tanah dan pemantapan agregat tanah. Bahan organik yang telah lapuk mempunyai kemampuan yang tinggi dalam menyerap dan menahan air (Hairiah et al, 2006). Selain itu, masuknya bahan organik ke dalam tanah yang terus menerus dari daundaun, cabang atau ranting yang berguguran, akar tanaman dan hewan yang telah mati dapat meningkatkan laju infiltrasi. Hal ini dapat terbentuk oleh terikatnya butirbutir primer bahan organik menjadi agregat tanah. Dengan meningkatnya laju infiltrasi dan pemantapan agregat tanah akan mengurangi limpasan air permukaan dan terjadinya erosi. Menurut Celik et al (2010), aplikasi biomassa tanaman dapat meningkatkan kandungan C-organik dalam tanah yang pada akhirnya dapat menurunkan berat isi tanah disertai dengan peningkatan porositas tanah. Dari hasil penelitiannya, Darmayanti et al (2016) melaporkan bahwa tingginya sisa serasah dapat berpengaruh nyata terhadap 
makroporositas terutama pada tanaman Terminalia,sp dibanding Dillenia,sp. Dalam hal hubungan ketebalan serasah dengan agregat tanah, Saputro (2005) mengatakan bahwa semakin tinggi serasah di suatu lahan menunjukkan kemantaban agregat yang semakin stabil (Tabel 1).

Tabel 1. Pengaruh ketebalan serasah terhadap pembentukan pori dan kemantaban agregat.

\begin{tabular}{llcc}
$\begin{array}{l}\text { Penggunaan } \\
\text { Lahan }\end{array}$ & $\begin{array}{c}\text { Serasa } \\
\mathbf{h} \\
(\mathbf{m m})\end{array}$ & $\begin{array}{c}\text { Porositas } \\
(\%)\end{array}$ & $\begin{array}{c}\text { DMR } \\
(\mathbf{m m})\end{array}$ \\
\hline Hutan Alami & 9.7 & 68 & 2.49 \\
\hline Kebon & 7.7 & 67 & 2.36 \\
Campuran & & & \\
\hline Bero & 6.7 & 61 & 23 \\
\hline $\begin{array}{l}\text { Lahan } \\
\text { Pertanian }\end{array}$ & 5.8 & 60 & 227 \\
\hline
\end{tabular}

Keterangan : DMR = Diameter Massa Rerata Sumber : Saputro (2005)

Dengan adanya pengaruh perakaran dan serasah terhadap makroporositas dan pengaruhnya yang positif terhadap infiltrasi, maka laju infiltrasi air hujan ke dalam tanah juga dapat ditingkatkan. Adanya aktivitas mikroorganisme dan hewan pengurai, mengakibatkan bahan organik yang terurai menimbulkan banyak ruang antara partikel tanah, sehingga makroporositas meningkat. Darmayanti (2012) mengatakan bahwa, makroporositas selalu berpengaruh secara nyata terhadap model kecepatan infiltrasi pada tegakan mahoni, trembesi dan jabon. Dari persamaan yang dihasilkan, peningkatan $1 \%$ makroporositas, dengan variabel lain bersifat konstan maka akan meningkatkan infiltrasi sebesar 17,3 cm/jam pada mahoni, $53 \mathrm{~cm} / \mathrm{jam}$ pada jabon, dan $17,4 \mathrm{~cm} / \mathrm{jam}$ pada trembesi. Berdasarkan nilai makroporositas ketiga pohon tersebut, nilai yang tertinggi adalah terletak pada tanaman mahoni, karena dipengaruhi perakaran mahoni yang lebih rapat dan potensi serasah mahoni yang lebih lama terdekomposisi.

\subsection{Peran Vegetasi Dan Perakaran Terhadap Mitigasi Erosi}

Erosi tanah adalah peristiwa terangkutnya tanah dari satu tempat ke tempat lain oleh air atau angin. Pada dasarnya ada tiga proses penyebab erosi yaitu pelepasan (detachment) partikel tanah, pengangkutan (transportation), dan pengendapan (sedimentation). Menurut Subandi (2014), pencegahan erosi dapat berlangsung secara efektif apabila paling sedikit $70 \%$ permukaan lahan tertutup oleh vegetasi. Efektifitas tanaman penutup dalam mengurangi erosi tergantung pada ketinggian dan kontinuitas penutupan, kerapatan penutup tanah dan kerapatan perakaran. Makin tinggi tanaman penutup makin tinggi efektifitasnya.

Adapun pengaruh vegetasi dan perakaran terhadap aliran permukaan dan erosi terjadi melalui :

a. Intersepsi hujan oleh tajuk tumbuhan. Butiran air hujan yang ditangkap tanaman kemungkinan terkumpul di daun dan membentuk butiran yang lebih besar. Dari tinggi jatuh sekitar $10 \mathrm{~m}$, kecepatan butir air hujan akan mencapai kecepatan terminal, yaitu kecepatan dimana pengaruh gesekan udara sama dengan pengaruh gravitasi, sehingga butir air hujan menjadi erosif.

b. Pengurangan laju aliran permukaan dan gaya dispersinya

c. Pengaruh akar dalam peningkatan granulasi dan porositas

d. Kegiatan biologi dalam tanah yang memperbaiki porositas, dan efek transpirasi yang mengeringkan tanah

Tanaman ataupun sisa-sisa tanaman berfungsi sebagai pelindung tanah terhadap daya pukulan butir air hujan maupun terhadap daya angkut air aliran permukaan (runoff), serta meningkatkan peresapan air ke dalam tanah. Keberadaan perakaran mampu memperbaiki kondisi sifat tanah yang disebabkan oleh penetrasi akar ke dalam tanah, menciptakan habitat yang baik bagi organisme dalam tanah, sebagai sumber bahan organik bagi tanah dan memperkuat daya cengkeram terhadap tanah (Agus et al., 2002). Perakaran tanaman juga membantu mengurangi air tanah yang jenuh oleh air hujan, 
memantapkan agregasi tanah sehingga lebih mendukung pertumbuhan tanaman dan mencegah erosi, sehingga tanah tidak mudah hanyut akibat aliran permukaan,meningkatkan infiltrasi, dan kapasitas memegang air. Peningkatan aktifitas mikroorganisme mengakibatkan peningkatan porositas tanah, sehingga memperbesar jumlah infiltrasi dan mencegah terjadinya erosi. Vegetasi memainkan peranan penting dalam fungsi penguatan dan membentuk rangkaian ikatan pada lapisan tanah. Keberadaan akar tanaman dapat mengurangi tegangan air pori positif dan memperbesar tegangan air pori negatif (Abdullah et al. 2011).

Zhang et al (2015), melakukan penelitian tentang efek vegetasi pada limpasan dan erosi tanah di tempat pembuangan tambang yang merupakan kunci untuk memulihkan ekosistem daeran yang sensitif secara ekologis. Dari hasil penelitiannya dilaporkan bahwa restorasi vegetasi memiliki dampak yang berbeda terhadap limpasan dan erosi tanah. Konservasi tanah yang paling efektif adalah pada bagian yang ditutupi dengan tanaman Robinia pseudoacacia dan Hippophae rhamnoides berumur 1 tahun. Pada bagian yang ditutupi dengan tanaman legum campuran berumur 5 tahun dan hutan semak belukar campuran berumur 5 tahun paling efektif secara keseluruhan dalam mencegah limpasan dan erosi tanah.

\section{KESIMPULAN}

Dalam jangka panjang, vegetasi dapat meningkatkan bahan organik tanah, memperbaiki sifat fisik tanah dan antierodibilitas tanah. Kuantitas perakaran dan serasah akan menentukan jumlah makroporositas tanah dan memantabkan agregat tanah. Dengan meningkatnya makroporositas tanah, maka laju infiltrasi semakin besar sehingga mengurangi besarnya air limpasan dan dapat memitigasi erosi.

\section{PERSANTUNAN}

Penulis mengucapkan terima kasih kepada Direktur Pusat Teknologi Reduksi Risiko Bencana (PTRRB), Dr. M. llyas, ST.,M.Sc dan semua pihak yang telah memfasilitasi penulisan sehingga dapat diterbitkan.

\section{DAFTAR PUSTAKA}

Abdullah, M.N., N. Osman dan F. H.Ali. 2011. Soil-root Shear Strength Properties of Some Slope Plants. Sains Malaysiana 40(10) (2011): 1065-1073.

Agus, F., A.Ng.Ginting, dan M. van Noordwidjk. 2002. Pilihan Teknologi Agroforestri/ Konservasi Tanah Untuk Areal Pertanian Berbasis Kopi di Sumberjaya, Lampung Barat. International Centre for Research in Agroforestry, Bogor.

Cardoso, E.J.B.N., R.L.F. Vasconcellos., D.Bini., M.Y.H. Miyauchi., C.A. dos Santos., Alves, P.R.L., A.M. de Paula., A.S. Nakatani., J.M. Pereira and M.A. Nogueira. 2013. Soil Health: Looking for Suitable Indicator. What Should be Considered to Assess The Effects of Use And Management on Soil Health? 274-298.

Celik, I., H. Gunal,. M. Budak and C. Akpinar. 2010. Effects of Long-term Organic And Mineral Fertilizer on Bulk Density And Penetration Resistance in Semi-arid Mediterranean Soil Conditions. Geoderma 160: 236-243

Darmayanti, A.S., E.E. Aryanti., L. Hakim. 2016. The Effect of Root And Litter on Soil Macroporosity of Terminalia microcarpa and Dillenia philippinensis in Purwodadi Botanical Garden. 2016. Journal of Biological Researches 21(1):8-12

Darmayanti, A.S. 2012. Beberapa Sifat Fisika Kimia Tanah Yang Berpengaruh Terhadap Model Kecepatan Infiltrasi Pada Tegakan Mahoni, Jabon, dan Trembesi di Kebun Raya Purwodadi. Staf Peneliti di Upt Bkt Kebun Raya Purwodadi, Pasuruan

Elfiati, D dan Delvian. 2010. Laju Infiltrasi Pada Berbagai Kelerengan Dibawah Tegakan Ekaliptus di Areal HPHTI PT. Toba Pulp Lestari Sektor Aek Nauli. Jurnal Hidrolitan I (2) 29 - 34 .

Farahani,

HA., SA.Valadabadi.,J.Daneshian., $\mathrm{AH}$. 
Shiranirad dan MA. Khalvati. 2009. Medicinal And Aromatic Plants Farming Under Drought Conditions. Journal of Horticulture and Forestry 1(6): 86-92.

Hairiah, K., H. Sulistyani., D.Suprayogo., Widianto., P. Purnomosidhi., RH. Widodo dan M. van Noordwijk. 2006. Litter Layer Residence Time in Forest And Coffee Agroforestry Systems in Sumberjava, West Lampung. Forest Ecology Management 224: 45-57.

Hanafiah, K.A. 2005. Dasar - Dasar Ilmu Tanah . Jakarta : PT. Raya Grafindo Persada. HIm.24.

Rindyastuti, R. \& AS. Darmayanti. 2010. Komposisi Kimia Dan Estimasi Proses Dekomposisi Serasah 3 Species Familia Fabaceae di Kebun Raya Purwodadi. Prosiding Seminar Nasional Biologi. Universitas Gadjah Mada. Yogyakarta.

Rivenshield, A \& NL. Bassuk. 2007. Using Organic Amendments to Decrease Bulk Density And Increase Macroporosity in Compacted Soils. Arboriculture \& Urban Forestry 33(2):140-146.

Sasal, MC., AE. Andriulo \& MA. Taboada. 2006. Soil Porosity Characteristics And Water Movement Under Zero Tillage in Silty Soils in Argentinian Pampas. Soil \& Tillage Research 87: 9-18.

Subandi, M. 2014. Comparing The Local Climate Change And Its Effects on Physiological Aspects And Yield of Ramie Cultivated in Different Biophysical Environments. Asian Journal of Agriculture and Rural Development 4 (11), 515-524.

Zhang, L., J. Wang, Z. Bai, C. Lv. 2015. Effects of Vegetation on Runoff And Soil Erosion on Reclaimed Land in An Opencast Coal Mine Dump in A Loess Area. Catena, Vol 128: 44 - 53. 